\title{
Three Good Reasons Why Foreign Language Instructors Need Neuroscience
}

\author{
Manuela Macedonia ${ }^{1,2}$ \\ ${ }^{1}$ Johannes Kepler University, Linz, Austria \\ ${ }^{2}$ Max Planck Institute for Human Cognitive and Brain Sciences, Leipzig, Germany \\ Science Park Gebäude S3 | Office S3 0131 | 4040 Linz, Altenbergerstrasse 69 \\ Tel: 43-699-1087-7243Ｅ-mail: manuela@macedonia.at
}

Received: August 23, 2013 Accepted: September 14, 2013 Published: November 1, 2013

doi:10.5296/jse.v3i4.4168

URL: http://dx.doi.org/10.5296/jse.v3i4.4168

\begin{abstract}
In the last three decades, brightly colored images of neural activity in the media have enhanced interest in brain functions. As a result, people have become more aware of the fact that cognition is not simply a black box. Instead, it consists of dynamic systems and mechanisms that respond to stimuli and which educators can exert influence on. In this paper the author shows how three areas of neuroscience are of crucial importance for L2 instruction. First a brief overview of studies is provided which show that words are not just encoded as labels for concepts, but rather are stored in brain networks together with the perceptions and actions that are relevant to them. From this point of departure the author goes on to demonstrate that sensorimotor encoding is the natural way to learn L2 vocabulary. Secondly, the concept of mirror neurons is introduced. They represent the neurobiological basis for imitation and are therefore essential for learning, particularly for the acquisition of languages. Thirdly, the author deals with brain maturation and elucidates its effects on L2-learning proficiency at different ages. These three lines of evidence suggest that knowledge of brain mechanisms is crucial for language teachers. Briefly stated, the aim of this paper is to help to bridge the gap between language instruction and neuroscience.
\end{abstract}

Keywords: Second, language, L2, Instruction, Teaching, Learning, Neuroscience, Network, Word, Imitation, Brain, Fiber tract, Style, Imaging 


\section{Macrothink}

\section{Introduction: What brain imaging can reveal about language}

When talking about brain imaging, cognitive neuroscientists refer to techniques that image functional metabolic changes in the brain. Whenever nerve cells process information, they become more active and their demand for „fuel”, i.e. either oxygen or glucose increases. Scanners can detect changes in oxygen and glucose consumption in every cubic inch of the brain. Brain images then reveal precisely where information processing or retrieval is taking place, and thus show which regions are involved in cognition. However, brain imaging is not able to tell exactly what the brain is doing. For example, language teachers would like to know what happens when a student reads a sentence in L2, but the colorful images can only reveal where it happens. In fact, language-regions and visual areas involved in reading display enhanced fuel consumption.

If that is the case, then what can brain images tell language teachers about language? The first neuroimaging study on language that yielded spectacular results was conducted on single words by Petersen et al. (1988). They made their subjects read, hear, articulate and generate words while lying in a scanner. The experimenters found that word processing elicited activity in different regions of the brain, in dependence on the task that the subjects were carrying out (Figure 1). When they (silently) read a word, a visual area specialized in letter processing was activated. Upon hearing the word, however, auditory regions above the ear processed the information. During word articulation, on the other hand, the scanner detected active neurons in an area of the motor cortex responsible for the control of mouth movements. Finally, when participants generated verbs from nouns, for example „buyer” from „to buy”, areas of the cortex that control language production displayed an enhanced demand for oxygen and glucose, the "fuel" of nerve cells.

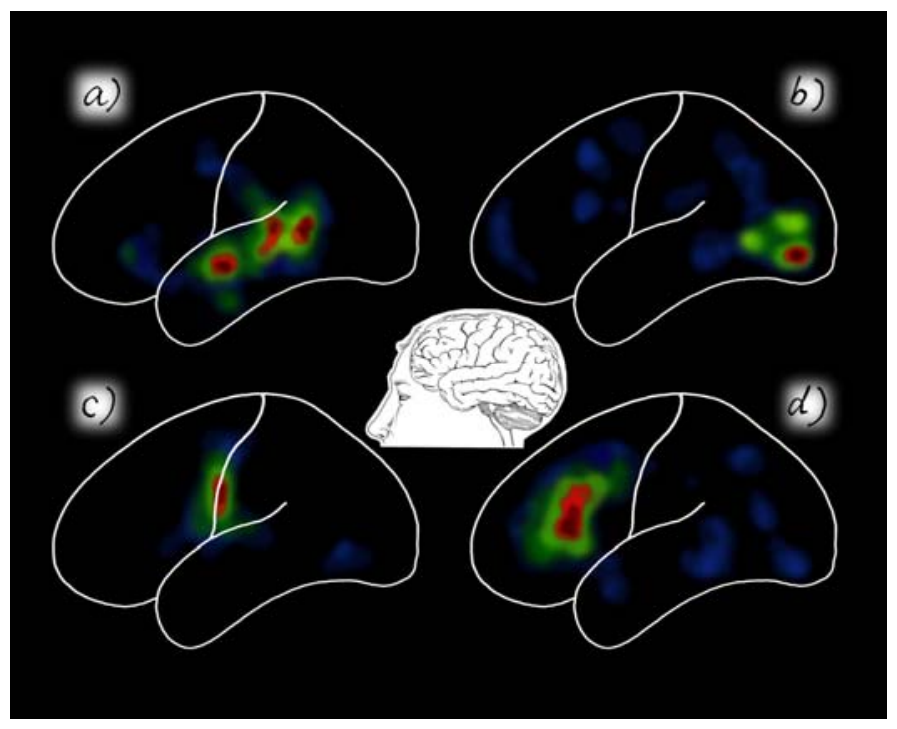

Figure 1. Words in the brain

Differences in brain topography and activity (blood flow) during word processing: a) hearing words b) reading words c) articulating words d) generating new words. Adapted from

Petersen et al 1988. Figure: courtesy of Klaus Pitter@. 


\section{Macrothink}

These results surprised many linguists. Up to that time, it had been generally believed that words were stored in the "lexicon" (Chomsky, 1965b), a kind of mental container, were retrieved from there and placed in the sentence according to syntactic rules. The results from the seminal paper of Petersen et al (1988) provided unexpected insights into language functions in the brain that seemed to invalidate the concept of the mental lexicon. Furthermore, the study also paved the way for a novel view, namely that language is a phenomenon of cognition resulting from the interaction of neural cell populations with each other. Since then, nearly three decades of intensive research have succeeded in localizing a number of phenomena in language processing in well-defined brain regions (see for a review Friederici, 2011). Thus, brain imaging nowadays provides us with a fine grained topography of language processing and helps to understand language functions.

\section{Reason \# 1: Word networks}

Among the discoveries concerning brain functions, the concept of the network is possibly the one that is most important for language teachers. When assemblies of neurons are excited by information coming from sensory channels they become active, i.e. they fire. Synchronous firing leads to metabolic changes within these cells and to growth processes in their projections. Axons and dendrites grow and synapses proliferate. Cells connect to networks that process and store information (Hebb, 1949).

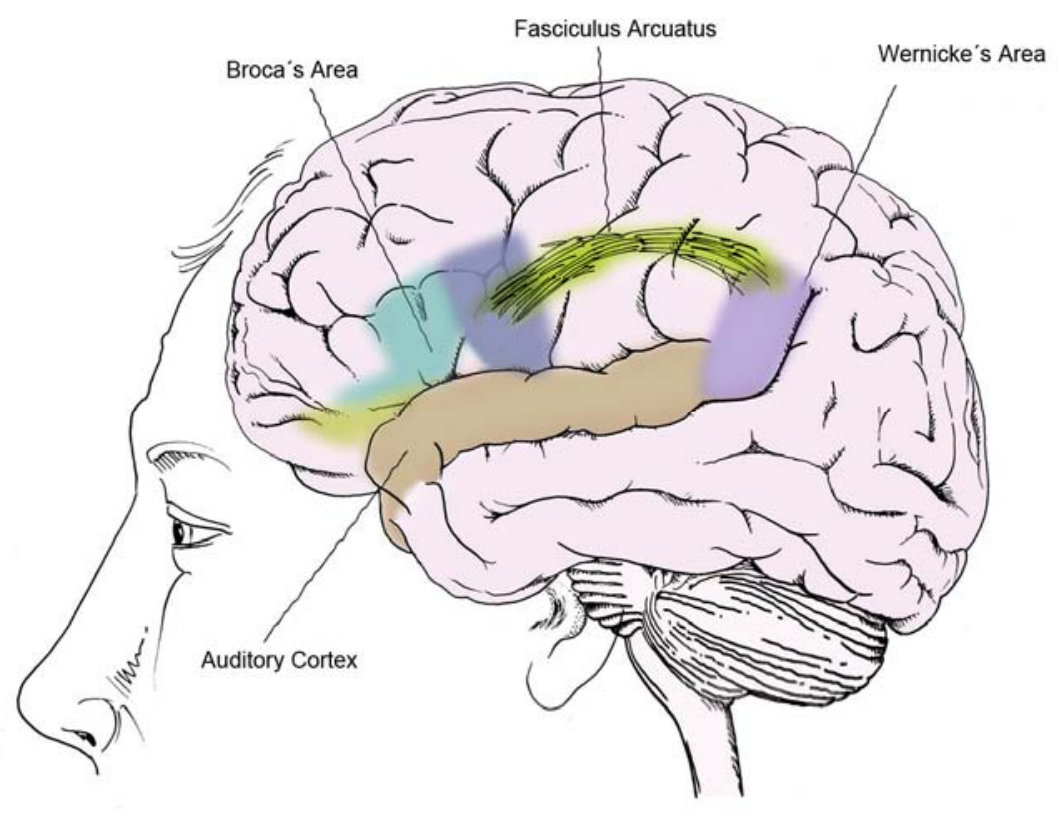

Figure 2. Classical language network.

It comprises Broca's area, involved in language production, Wernicke's area and they auditory cortex which makes language perception and understanding possible. The fascicuclus arcuatus is a fiber bundle consisting of myelinated axons that connects the core areas of the language network. Figure: courtesy of Klaus Pitter@).

For a long time it has been known that language functions reside in language areas, i.e. 
Broca's and Wernicke's areas. In these regions, large scale networks process language production and perception. Single word learning is also driven by networks, however. A number of experiments have shown that a word is represented in the brain in the form of a network which stores the sensory information and experience that was collected during its acquisition (Pulvermüller, 1999). For example, when an infant interacts with an orange, it perceives the shape, color, smell, taste and texture of the fruit. At the same time, it hears the name of the fruit from its caregivers, and at some later point in its life, it tries to articulate that word. All this information is interconnected in the form of a network for the concept (Gallese \& Lakoff, 2005). The word which the child hears from its caregivers is therefore not an abstract unit, a symbol or a „labeled concept” (Bierwisch, 1999) in the child's brain, as earlier theories of cognition maintained (Fodor, 1976, 1983; Fodor, Bever, \& Garrett, 1974). Instead, the word - the sequence of phonemes - is one component of the network which codes the interaction of the child with the fruit (Figure 3). Finally, since a person accumulates new experience with oranges in the course of his lifetime, the network for the word will change depending on that experience. Suppose that the child - at another point in time - grasps an immature fruit: it will have an unusual taste, probably smell differently than a mature one and its color will be paler. Then that child's network for oranges will also enlarge and come to include the representation of the characteristics of the immature orange. Word networks have been successfully imaged in a number of experiments. For example, Gonzales and colleagues (2006) were interested in determining whether odor words like „cinnamon” are represented with olfactory components in the brain. In the scanner, the authors presented participants with written words like garlic, jasmine and cinnamon. In their brains, merely reading them elicited activity not only in language areas but also in primary olfactory regions of the brain.

Not only odor produces this kind of effect. In a study by Small and colleagues (2012), participants read words whose primary meanings were related to taste and control words during brain imaging. All of these words activated areas involved in language production and language perception (i.e. Broca's and superior temporal gyrus, BA 21/22), but only the taste words elicited stronger activity in gustatory brain regions and others in the anterior insula, which is known to become active during taste perception and processing. In another experiment, Olaf Hauk and co-workers investigated whether words that indicate actions are also represented in the brain together with the limb(s) involved in the action. The experimenters made participants read words like „pick”, „kick” and „lick” that differ from each other only by one sound and whose performance involves different parts of the body. As expected, reading these words activated brain regions in the motor cortex that were respectively related to hand and arm, foot and face movements (Hauk, Johnsrude, \& Pulvermuller, 2004). Carota and colleagues (2012) wanted to find out whether the reading of object-related words would show different topographies in the brain depending on the semantic content of the words. They used three types of lexical items which semantically belong together: words for animals, for food, and for tools. Whereas animal words did not produce any consistent effects, food-words elicited activity in the portion of the motor cortex controlling tongue movements. Furthermore, the left orbitofrontal cortex, a region in the forebrain related to food appraisal, also became active. Tool-words activated the finger motor cortex and the right cerebellum, i.e. areas involved in action processing and execution. 


\section{Mll Macrothink}

Altogether, these examples show that the lexicon is not an abstract cognitive phenomenon. Rather, words are tightly connected to the experiences we make with our bodies (Fischer \& Zwaan, 2008; Gallese \& Lakoff, 2005). Words thus link perception and action to form functional units (Pulvermüller, 2002; Setola \& Reilly, 2005) that appear in brain imaging as distributed cortical networks (Macedonia, Müller, \& Friederici, 2011).

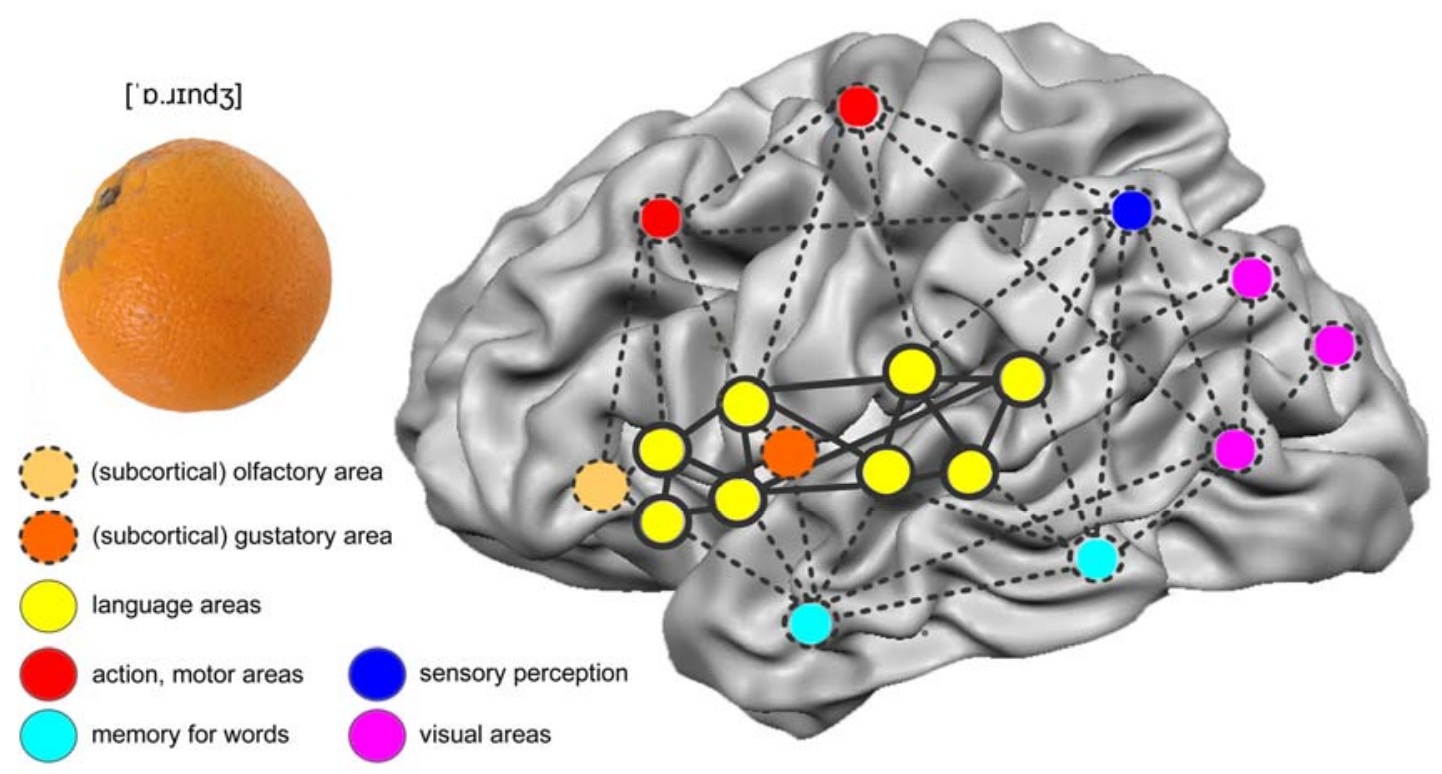

Figure 3.Word network for orange.

Besides the canonical language areas in yellow (Broca's and Wernicke's regions, auditory cortex) the network for orange comprises areas processing and storing visual information of different types (odor, taste, color, shape, etc.), as well as areas related to sensory perception (pink) and to preparation for and execution of action (red), when the fruit is being manipulated.

How does this affect language teachers? If words are encoded and stored in multimodal networks in natural learning, there is no plausible reason why this process should not be reconstructed during foreign language instruction. That means that words in L2 should be learned by involving all sensorial channels as well as the body. In fact, it has been proven that multisensory learning is more effective that unisensory learning (Seitz, Kim, \& Shams, 2006; Shams \& Seitz, 2008; Shams, Wozny, Kim, \& Seitz, 2011; Von Kriegstein \& Giraud, 2006). It is well known that enriching a word that is written in the foreign language with additional information, like a picture on a flash card, makes it easier to retain that word (Clark \& Paivio, 1991; Paivio, 1971; Paivio, 2006). A number of experiments in the last decades have shown that gestures as well as other forms of input enrichment also facilitate the retention of verbal information (Zimmer, 2001; Zimmer \& Engelkamp, 2003). When vocabulary items in L2 are accompanied by an iconic gesture, they are more readily memorized (see for a review Macedonia \& Von Kriegstein, 2012). Macedonia and colleagues tested this procedure repeatedly and found that gestures enhance memory retention for single words in the short as 
well as in the long term (Macedonia, 1996, 2003; Macedonia et al., 2011). In a recent study Macedonia \& Knösche (2011) investigated whether gestures also support the learning of abstract words. For them, gestures cannot depict objects, hence they must be symbolic and arbitrarily invented by the user(s). The results confirmed the hypothesis: also symbolic gestures significantly enhance word learning. In the same study, the authors showed that words learned with gestures are more often used in language production, i.e. when creating novel (non-canonical) sentences, than words learned audiovisually. Verbal information memorized with multisensory input thus proved to be more easily accessible, so that this form of enrichment was shown to enhance language learning.

Despite this empirical research, the different theories on learning styles (Entwistle \& Peterson, 2004; Pashler, McDaniel, Rohrer, \& Bjork, 2008) which are very influential in contemporary Western instruction recommend that we focus on single learning modalities in order to meet the personal needs of the learner (Hawk \& Shah, 2007). However, when we only learn visually or acoustically, learning is deprived of what it needs, namely of the sensorimotor components that are necessary for the formation of extended networks like depicted in Figure 3. Depriving learning of multimodal input makes it unnatural, and possibly even inefficient. It is remarkable that learning type theories do not take empirical research on learning into consideration. They simply make it mandatory to impoverish the learning process and to provide each learning type exclusively with its "favorite" kind of lesson. Interestingly, most of the tests that assess learning types rely on self-reporting (Soloman \& Felder, 2013) and have not been validated. Often, the information they evaluate is not adequate for the formulation of a sustainable hypothesis on learning style, and it is questionable if these styles really exist. In a review article, Pashler et al. (2009) refer to tests revealing some preferences in learning styles. The authors maintain that even if learning types really do exist, their practical implications for language instruction are „minimal”. For this and other reasons, the Brain and Learning project of the Organization for Economic Co-operation and Development (OECD) regards the learning type theory as a neuromyth (OECD, 2002). Even if a person does have an auditory learning preference, that does not mean that he/she should only be provided with acoustic input, and other possibilities i.e. encoding channels that would optimize the learning process should be rejected.

To sum up, the brain stores information in networks that are related to sensorimotor experience and not, as theories of learning styles maintain, in the form of isolated entities. Networks in the brain constitute the bases for all kinds of learning and enable the acquisition of vocabulary in native as well as foreign languages. Therefore, in order to make learning natural and thereby successful, L2 trainers should consider ways of involving sensorimotor modalities when teaching vocabulary. Flash cards that enrich the words visually (Paivio, 2006) are popular in practice, but also more complex classroom activities and games (Macedonia, 2005) are suitable for engaging manifold sensory modalities and the motor system in the L2-learning experience.

\section{Reason \# 2: Imitation learning and mirror neurons}

In the 1970ies, Meltzhoff published a seminal study showing that human neonates between 
12 and 21 days of age imitate facial and manual gestures of adults (Meltzoff \& Moore, 1977). The author concluded that this behavior cannot have been learned at this age and that it must be inborn. Since then, the onset age of imitation has been revised, so that it is now considered to be several months after birth (Jones, 2009). Nevertheless, laboratory research has demonstrated that imitation is a natural kind of learning behavior for social skills (Over \& Carpenter, 2012; Schwier, van Maanen, Carpenter, \& Tomasello, 2006) as well as language (Bannard, Klinger, \& Tomasello, 2013). Interestingly, imitative behavior is considered as a predictor of normal cognitive development. In developmental disorders like autism, imitation is disrupted, which coincides with a retardation in language acquisition (Diehl \& Paul, 2012). Imitation also seems to give rise to learning in other animals like monkeys, birds (Zentall, 2004) and dolphins (Herman, 2012). These species also learn their vocal displays from their close associates (King, Sayigh, Wells, Fellner, \& Janik, 2013), hence by imitating their „language”.

There is also one more reason to assume that imitative learning of pronunciation is inborn. In the mid1990s, the team of Giacomo Rizzolatti investigated the physiology of grasping movements in macaques. The team was particularly interested in a group of neurons that control movements of the arm and mouth when the monkey reaches for food, manipulates and eats it. The scientists had implanted deep electrodes in a portion of the motor cortex of the animals and were recording the electrical activity of neurons involved in these actions. One day, a monkey was sitting and observing the experimenters, when one of the experimenters accidentally thrust his hand into a basket containing food rewards. The implanted neurons in the monkey's brain fired at a rate as if the animal was performing the action itself, although it did not move at all. In the seminal paper that followed this discovery, Gallese and colleagues (1996) proclaimed the existence of neurons which resonate actions performed by others, and hence are termed „mirror neurons”. Since 1996 a large number of studies have been conducted and have proven the existence of mirroring circuits in the brain (see for a review Casile, 2013). In the scientific community there is common agreement that mirror neurons underpin resonance behaviors (Rizzolatti, Fadiga, Fogassi, \& Gallese, 1999), i.e. they enable observers to simulate and thereby to understand other people's actions. Most interestingly for educators, mirror neurons can be regarded as the neurobiological motor which drives learning (Marco Iacoboni, 2009; Rizzolatti, 2005; Rizzolatti \& Craighero, 2004) from others (Rizzolatti, Fadiga, Fogassi, \& Gallese, 2002). Particularly language perception, production and acquisition seem to be driven by mirror neuron circuits from both a phylogenetic and an ontogenetic perspective (Glenberg \& Gallese, 2012). Dysfunctions in mirror neuron circuits underlie developmental disorders (Iacoboni \& Dapretto, 2006), such as autism spectrum disorder (Oberman \& Ramachandran, 2007) in which imitation learning is compromised. 


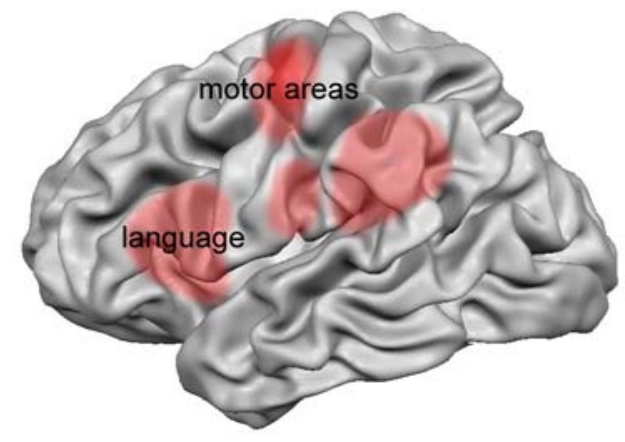

Figure 4. Mirror neurons circuits in the brain

Color coded regions show the approximate location of mirror neurons circuits.

Adapted from a comprehensive review by Hamilton, 2013.

What has all this to do with L2-teaching and learning? The facet of L2-teaching that definitely could take advantage of imitation is pronunciation. Classroom pronunciation training mainly consists of listening activities (Berne, 1998; Bradlow, Akahane-Yamada, Pisoni, \& Tohkura, 1999) and does not provide conditions comparable with L1 acquisition. In „Teaching pronunciation” (Celce-Murcia, Brinton, \& Goodwin, 2010), a book for teachers which is now in its 10th edition and is widely used in the education of L2-teachers, no attention is devoted to imitation. Also, some practitioners assert that imitation is not relevant to pronunciation (Messum, 2012). Despite this, over the decades empirical science has made extensive effort to documenting that imitation is a powerful mechanism in language learning in terms of operant conditioning (Kymissis \& Poulson, 1990; Masur \& Rodemaker, 1999), whereby reinforced input is provided by interaction (Olson \& Masur, 2012). A further argument for imitation comes from first language acquisition, where babies are „taught” by means of the natural mechanism designated as motherese. It is a behavior which serves to provide the infant with extensive linguistic input (Kuhl, 2007). Motherese encourages the child to interact with the caregiver(s) and to reproduce the sounds (s)he perceives. Thus in motherese, acoustic and visual perception of articulatory gestures and their reproduction, i.e. imitation, play a key role. In L2 instruction, pronunciation training could be employed in a similar manner and would represent a natural method of learning sounds.

In the 1970ies, Liberman and Mattingly developed the Motor Theory of Speech Perception. It focuses on the interdependency of speech perception and production and asserts that speech is perceived by reference to the articulatory gestures needed to produce it (Liberman \& Mattingly, 1985). Hence, we understand sounds that we can generate and that we have been trained to generate. For example, klick consonants occurring in Khosan languages of Western and Southern Africa are highly unfamiliar to speakers of other languages and also difficult to pronounce. When trying to articulate a click, we do not know exactly what to do with our tongue and how to direct the airstream that sometimes is ingressive and does not emerge from the mouth. Simply perceiving the clicks does not enable us to reproduce them. Similarly, a 
prominent example known to everybody is the English dental fricative „th” [ð]. This sound is difficult for non-natives to pronounce. It is common knowledge that Italians turn it into [f]. They substitute the phoneme they have no articulatory motor pattern for with a sound available in their native language inventory. Similarly, natives of German turn a perceived [ð] into an articulated [z] or a [d]. If pronunciation training is only based on listening, learners store an acoustic pattern that allows them to recognize the sound when they hear it. However, this is not the motor pattern needed for articulation of the sound. It does not provide the information the speaker would need on how to shape and sequence airstream, tongue, teeth, lips, and so on. We must pose the question as to whether L2-learners can construct a motor representation of the sound without having seen how to do it?

When imitating novel sounds in L2 by means of audiovisual observation and interaction, mirror neurons might be responsible for accomplishing the interaction between sound perception and sound reproduction. Imitation via mirror neurons maps action into sound: the learner sees the motor act performed when the L2-speaker produces language sounds and through mirroring mechanisms trains and maps sound production into his own motor cortex. The direct link between action perception and reproduction has been empirically documented over the years (Prinz, 1997; Zwickel \& Prinz, 2012). Perception and action use a common code (Massen \& Prinz, 2009) and share the same neural substrate (Prinz, 2003).

Interesting insights on how mirror neurons connect observation and action are provided by stroke rehabilitation studies. In the past, patients (re)learning impaired motor functions were connected to robotic devices that moved their limbs passively (Pennycott, Wyss, Vallery, Klamroth-Marganska, \& Riener, 2012), but new therapies encourage patients to observe and imitate videotaped actions (see for a review Small, Buccino, \& Solodkin, 2012). Patients are thus trained to first observe, then imagine how to reproduce actions and finally to imitate them. Most interestingly, this is not only the case in limb prosthesis therapy, but also in language rehabilitation. In a computer based therapeutic approach called IMITATE aphasics are cued to imitate audiovisual speech (Lee, Fowler, Rodney, Cherney, \& Small, 2010).

As previously noted in this paper, imitation is not regarded as a major technique in L2 instruction. This might be due to the controversy between behaviorists and nativists which has not yet been resolved in the field of language education (López Ornat \& Gallo, 2004). In „Verbal Behavior”, Skinner (1957) asserted that language - like other behaviors - is learned as a product of operant conditioning. According to this theory, imitation would be one of the behaviors leading to language acquisition. Chomsky (1959) reviewed Skinner's book and harshly criticized it. He proposed a completely different view of language, considering it as an innate, non-learnable phenomenon of our minds. Chomsky's view would imply that language emerges by itself, because it is inborn. Hence, children would acquire a language without having to imitate caregivers. Chomsky's criticism was so influential that some authors refer to it as the paper which marked the decline of behaviorism in the cognitive sciences and, most importantly, in linguistics (Miller, 2003). The reluctance to employ imitation as an instructional method in L2 language education might possibly be a result of this seminal contribution of the father of nativism who - as we know - still dominates linguistic thought and therefore is still very influential in the education of teachers. However, 
we are now familiar with brain mechanisms that are responsible for learning through imitation, and there can be no doubt that listening activities must be enriched through multisensory input in order to achieve accurate pronunciation in L2.

\section{Reason \# 3: Brain maturation and early L2 lessons}

It would be difficult to find parents who do not advocate multilingualism in their children. Although there is overall consensus that language training should take place in early years, controversy exists as to when L2 should begin. In Western countries, there are (mostly private) institutions like for example English kindergartens that start L2 at around the age of 3. In the same countries, schools provide L2 instruction at 7 or even later. In the past, two influential concepts have indirectly advocated early L2 learning. Maria Montessori described „sensitive periods” (Montessori \& Claremont, 1969), i.e. developmental phases in which the child responds particularly well to stimuli. Noam Chomsky (1965a) propagated the Language Acquisition Device (LAD), that is intended to enable children to acquire their native language without direct instruction and even if they are provided with little stimulus by caregivers (poverty of the stimulus argument). However, neither Montessori nor Chomsky has made any recommendations in regard to an onset age for $\mathrm{L} 2$.

In a state-of-the-art article, Muñoz \& Singleton (2011) reviewed research on ultimate L2 attainment and its relation to the age of onset. They concluded that the optimal age of L2 onset is closely related to the quality and intensity of input as well as to the attitude of the learners. In a recent study Cepik \& Sarandi (Cepik \& Sarandi, 2012) investigated the effects of early (5-6ys) and late L2 (9-10ys) in 83 Turkish children attending private schools by administering tests on the four language skills. The authors could not find any significant differences in the two groups, but they did detect „a more positive attitude towards English” in early starters. In a behavioral study, Granena and Long (2013) investigated the relationship between the age of onset (AO) in L2 and final attainment. Sixty-five Chinese learners of Spanish were subdivided into three groups according to the AO: 3-6, 7-15, and 16-29 years. Participants were subministered language tests in phonology, lexis, morphology and syntax. The results of the phonological test show that AO plays a major role in pronunciation. Only the group with AO 3-6 scored in the vicinity of the natives. However, the decline in pronunciation proficiency began in this group and progressed dramatically with age. Lexis and morphosyntax accuracy also correlated with AO, but, the „overall decline in performance as a function of AO was the steepest in the area of phonology”.

It is common knowledge that a little child does better at learning than an (older) adult. In terms of the brain, what does this depend on? In a review, Uylings (2006) addresses the question of sensitive periods in the development of the brain, particularly in respect to the plasticity of its surface, i.e. of the cortex. The author lists a number of processes that are particularly efficient during the first years of life: the development of dendrites and synapses and the creation of functional experience-related networks for storing and processing language. Although cortical plasticity is a phenomenon that does not stop at adult age, it seems to be much easier to learn language during childhood. Uylings mentions feral children that spend their first years of life in isolated conditions and afterwards are not able to achieve 
accuracy in either spoken or signed languages. On the base of reviewed literature, the author sees a critical period from birth until the age of 7, after which learners are no longer able to attain native-like proficiency in L2. However, Uylings points to the fact that in L2-learning nature and nurture cannot be disentangled, i.e. that many other factors can play a role in proficiency besides the age of onset.

In the last few years new studies in brain development provide novel support for maturational constraints. Whereas in the past considerable attention has been devoted to networks on the surface of the brain, attention is now focussed on white matter. White matter consists of glial cells that embed axons, the projections of neurons conducting information (electrical impulses) away from the cell body. Axons bundle together to form fiber tracts, that are detectable by a neuroscientific method called diffusion tensor imaging (DTI) (Mori, Oishi, \& Faria, 2009). During childhood, axons grow and are insulated by myelin, a substance supplied to the neurons by glia cells. Myelination is essential for axons because it because it enhances the speed with which information travels through the brain. As for language functions, for a long time it has been known that the fibers of the arcuate fasciculus connect Wernicke's area - language understanding - with Broca's area - language production (Figure 2). The Wernicke-Geschwind model of language processing (Geschwind, 1970; Wernicke, 1874), explained conduction aphasia in terms of lesions in the arcuate fasciculus and has been familiar to linguists and neurologists for many decades. However, until the event of DTI it was not known that these fibers in the language network are not limited to the arcuate fasciculus and that at birth they are not yet fully developed. In a review paper, Friederici (2009) describes several pathways connecting Broca's and Wernicke's areas. One of them, the so called „dorsal pathway” processing complex syntax partly corresponds to the arcuate fasciculus. Interestingly, this fiber tract it is not present in non-human primates and it might be one of the main structures responsible for the ability of humans to learn syntax and linguistic complexity. In a study with functional magnet resonance imaging, Perani et al. (2011) investigated the language network in 2-day-old infants. During the scanning procedure, the babies were presented with speech. Thereafter, their brain activity and structure were compared to those of adults. The results show that cortical regions processing speech are nearly the same in newborns as in older children and adults. By contrast, major differences were found in the anatomy of the young brains. The dorsal fiber tract which is responsible for syntax was not detectable in the babies, but was well developed in the adults. In contrast, the so called ventral fiber pathway, which supports phonetic processing (Saur et al., 2010) and therefore is involved in phoneme learning, was already present at birth. Brauer et al. (2013) compared the development of both the dorsal and ventral fiber pathways in three different groups of subjects: newborns, 7-year-old children and adults. In doing so, their intention was to observe how the maturation of white matter progresses over the course of time and in relation to language acquisition. The authors observed a primacy in the maturation of the ventral pathway and confirmed the results of previous studies. In contrast to Perani et. al. (2011) Brauer and colleagues were also able to detect dorsal fibers, which however are very sparse at birth and do not connect Broca's with Wernicke's areas. 


\section{MInstitute Macrothink}

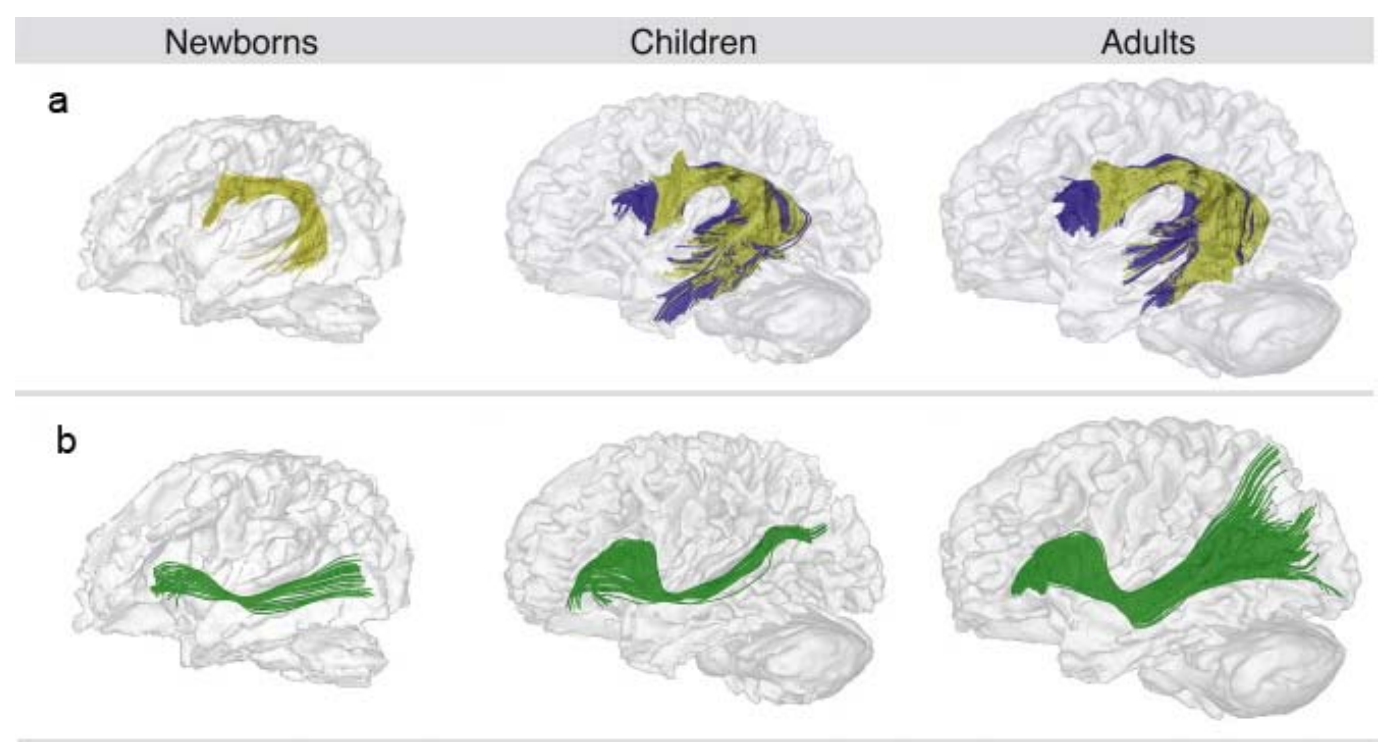

Figure 5. Fiber pathways connecting language areas in the brain during development

Dorsal (a) and ventral (b) pathways of the language network in the brain of newborns, children ( 7) and adults according to Brauer et al., 2013. Dorsal pathways are considered crucial in complex language processing (syntax) and develop later during childhood. Ventral pathways, which serve phonetic and phonological language processing, are already at place after birth. Figure: courtesy of Jens Brauer.

Lebel et al. (2008) investigated the maturation of 10 different fiber tracts which are crucial for cognition in the first 30 years of life on a cohort of 202 subjects (5-30 years). In the language pathway(s), the authors found an average peak of maturation at the age of 5 . Thereafter, the maturation process slows down and bottoms out around the age of 10. It then continues at the same level until the age of 30. Considering that these fiber tracts not only serve L1 but also L2, the „sensitive period” for L2 learning does indeed lie within the first 7 years of life, with a time core between birth and 5years.

Altogether, the results of neuroscientific studies support the observation that not all language skills are acquired at the same time in development. Considering the maturation of the ventral fiber tract and its functioning at birth, the acquisition of phonology must take place very early in development. Accordingly, the development of a native-like phoneme inventory in L2 will be facilitated if the age of onset is also very early in life. Given that the maturation of the dorsal fiber bundles supporting morphosyntax occurs later in infancy, L2-accuracy in this domain can be expected to be native-like even if a child starts learning L2 „later”, i.e. in primary school. Hence, if the aim of L2 instruction is to attain native-like pronunciation, the onset age must be very early in childhood. If the target is correct grammar, however, the onset age can be 3/4 years later, but as Granena and Long (2013) have convincingly shown, not in adolescence, as the capacity to attain L1-like competence dramatically declines after childhood. 
Neuroscientific knowledge supplies the concepts of „sensitive period” and „language acquisition device" with an empirically measurable dimension in time and explains behavioral data in a new light. Moreover, since we now know that language maturation processes, hence the possibility of learning L2 with a native like proficiency, bottom out roughly at age 10, it is necessary to reconsider the onset age of L2 instruction. It is certain that final L2 attainment does not uniquely depend on the age of onset, but also on the quality of instruction, the intensity of exposure, the aptitude towards L2 and other factors documented in the literature. Nevertheless, if L2 educators know and understand the neural mechanisms that are involved, reaching native-like bilingualism will be a realistic target in the future.

\section{Conclusion: Do L2-instructors really need neuroscience?}

In the last few years, it seems that the original enthusiasm towards the brain has given way to cool caution. Additionally, the effort to make neuroscientific knowledge accessible to educators has been criticized. Apparently, teachers only have superficial knowledge about the brain (Mason, 2009), which leads to the creation of neuromyths (Alferink \& Farmer-Dougan, 2010; Christodoulou \& Gaab, 2009). Recently Dekker et al. (2012) tested 242 primary and secondary school teachers in the United Kingdom and the Netherlands on their knowledge of the brain and learning. Participants were asked to complete an online survey comprising 47 statements, among which 15 were neuromyths (i.e. „Short bouts of co-ordination exercises can improve the integration of left and right hemispheric brain functions"). $49 \%$ of the teachers believed in the neuromyths presented during testing. The authors of the study conclude that teachers are not able to distinguish between scientific facts and pseudoscience, especially if the pseudoscience is successfully marketed as "brain-based,, education (Pasquinelli, 2012). Basic knowledge of the brain can thus enable us to discern between opinions and empirically proven methodologies in language teaching. For example, let us consider the theory of learning style: There is no scientific evidence that the brain learns more or better with one or the other sensory modality. It is simply a myth. Why then has this theory then become so popular and why is it still so influential? Pashler et al (2009) explain that the „industry” of the learning style publishes and sells assessment devices, textbooks for learners, literature for teachers and workshops for teachers. All this has become a business branch with sellers on the spot that have a vested interest in maintaining the neuromyth because they make their living with it. This matches well with the understandable wish of parents to have their children treated as individuals with unique capacities. Thus, parents desire personalized training in order to best develop their child's capacities. Hence, sellers and parents advocate learning types and teachers see themselves compelled to take them into consideration. Neuroscientific knowledge would enable teachers and parents to avoid this pitfall.

In defense of L2 practitioners, one has to consider that educational curricula of language teachers do not comprise the basics of neuroscience. Furthermore, even most engaged teachers have no access to primary literature on the brain. Neuroscientific research is published in journals written for professionals and not easily understandable to readers trained in other fields. There is no way for teachers to think critically about a topic they have no basic knowledge of. Demanding that they do so would be the same as insisting that 
patients should think critically about the components of a medicine they are taking. Although prominent neuroscientists such as Uta Frith (2005) and Michael Posner (Posner \& Rothbart, 2005) have long advocated the necessity for communication between neuroscience and education and have encouraged cooperation between these disciplines, the dialogue remains difficult. This might also be due to the lack of knowledge transfer. From the other side of the trench, language instruction reproaches neuroscience for treating the mind in a reductive manner. „Neuroscientists study cognitive functions in isolation for the sake of simplicity” (Willingham, 2009). It is true that methods used by natural sciences must slice cognitive phenomena into neat portions in order to be able to answer questions with empirical evidence. This restriction is thus methodologically determined.

Have the numerous attempts to establish a dialogue between the natural sciences and the humanities, between neuroscience and L2 education, all been in vain? Besides acknowledging the existence of misconceptions about the brain and neuromyths, the author trusts that in the next years enough scientific knowledge will trickle through to educators. The author concludes that understanding L2 learning processes in the brain constitutes the basis for any successful pedagogical approach. Besides protecting instructors from fashions, trends and pseudoscientific misconceptions in education, it is the key to efficacious L2 teaching and learning.

\section{Acknowledgement}

The author wishes to thank Dr. Stephen Sokoloff for helpful discussion on the topic. This work was supported by a grant from the Cogito Foundation, Wollerau (Switzerland).

\section{References}

Alferink, L. A., \& Farmer-Dougan, V. (2010). Brain-(not) Based Education: Dangers of Misunderstanding and Misapplication of Neuroscience Research. Exceptionality, 18(1), 42-52. http://dx.doi.org/10.1080/09362830903462573

Bannard, C., Klinger, J., \& Tomasello, M. (2013). How Selective Are 3-Year-Olds in Imitating Novel Linguistic Material? Dev Psychol. http://dx.doi.org/10.1037/a0032062

Berne, J. E. (1998). Examining the relationship between L2 listening research, pedagogical theory, and practice. Foreign Language Annals, 31(2), 169-181. http://dx.doi.org/10.1121/1.418276

Bierwisch, M. (1999). Words in the brain are not just labelled concepts. Behavioral and Brain Sciences, 22(2), 280-282. http://dx.doi.org/10.1017/S0140525X99221826

Bradlow, A. R., Akahane-Yamada, R., Pisoni, D. B., \& Tohkura, Y. (1999). Training Japanese listeners to identify english /r/and /1/: Long-term retention of learning in perception and production. Perception and Psychophysics, 61(5), 977-985.

Brauer, J., Anwander, A., Perani, D., \& Friederici, A. D. (2013). Dorsal and ventral pathways in language development. Brain and Language. http://dx.doi.org/10.1016/j.bandl.2013.03.001

Carota, F., Moseley, R., \& Pulvermüller, F. (2012). Body-part-specific Representations of Semantic Noun Categories. Journal of Cognitive Neuroscience, 24(6), 1492-1509. 
http://dx.doi.org/10.1162/jocn_a_00219

Casile, A. (2013). Mirror neurons (and beyond) in the macaque brain: an overview of 20 years of research. Neurosci Lett, 540, 3-14. http://dx.doi.org/10.1016/j.neulet.2012.11.003

Celce-Murcia, M., Brinton, D., \& Goodwin, J. M. (2010). Teaching pronunciation: a course book and reference guide (2nd ed.). New York: Cambridge University Press.

Cepik, S., \& Sarandi, H. (2012). Early and late language start at private schools in Turkey. Kuram ve Uygulamada Egitim Bilimleri, 12(Suppl. 4), 3199-3209.

Chomsky, N. (1959). A review of B. F. Skinner's "Verbal Behavior". Language, 35, 26-58.

Chomsky, N. (1965a). Aspects of the theory of syntax. (Second printing.). Cambridge, Mass: M.I.T. Press.

Chomsky, N. (1965b). Syntactic structures. The Hague,: Mouton.

Christodoulou, J. A., \& Gaab, N. (2009). Using and misusing neuroscience in $\begin{array}{llll}\text { education-related } \quad \text { research. } & \text { Cortex, }\end{array}$ http://dx.doi.org/10.1016/j.cortex.2008.06.004

Clark, J., \& Paivio, A. (1991). Dual coding theory and education. Educational Psychology Review, 3(3), 149-210. http://dx.doi.org/10.1007/BF01320076

Dekker, S., Lee, N. C., Howard-Jones, P., \& Jolles, J. (2012). Neuromyths in education: Prevalence and predictors of misconceptions among teachers. Frontiers in Psychology, 3(OCT). http://dx.doi.org/10.3389/fpsyg.2012.00429

Diehl, J. J., \& Paul, R. (2012). Acoustic Differences In The Imitation Of Prosodic Patterns In Children With Autism Spectrum Disorders. Res Autism Spectr Disord, 6(1), 123-134. http://dx.doi.org/10.1016/j.rasd.2011.03.012

Entwistle, N., \& Peterson, E. (2004). Learning Styles and Approaches to Studying. In S. Editor-in-Chief: Charles (Ed.), Encyclopedia of Applied Psychology (pp. 537-542). New York: Elsevier.

Fischer, M. H., \& Zwaan, R. A. (2008). Embodied language: A review of the role of the motor system in language comprehension. Quarterly Journal of Experimental Psychology, 61(6), 825-850. http://dx.doi.org/10.1080/17470210701623605

Fodor, J. A. (1976). The language of thought. Hassocks: Harvester Press.

Fodor, J. A. (1983). The modularity of mind: an essay on faculty psychology. Cambridge, Mass.; London: MIT Press.

Fodor, J. A., Bever, T. G., \& Garrett, M. F. (1974). The psychology of language. An introduction to psycholinguistics and generative grammar. New York, etc.: McGraw-Hill Book Co.

Fragaszy, D., \& Visalberghi, E. (2004). Socially biased learning in monkeys. Learn Behav, 32(1), 24-35. http://dx.doi.org/10.3758/BF03196004

Friederici, A. D. (2009). Pathways to language: fiber tracts in the human brain. Trends in Cognitive Sciences, 13(4), 175-181. http://dx.doi.org/10.1016/j.tics.2009.01.001

Friederici, A. D. (2011). The Brain Basis of Language Processing: From Structure to 
Function.

Physiological

Reviews,

91(4),

1357-1392.

http://dx.doi.org/10.1152/physrev.00006.2011

Frith, U. (2005). Teaching in 2020: the impact of neuroscience. Journal of Education for Teaching: International research and pedagogy, 31(4), 289-291. http://dx.doi.org/10.1080/02607470500280118

Gallese, V., Fadiga, L., Fogassi, L., \& Rizzolatti, G. (1996). Action recognition in the premotor cortex. Brain, 119(2), 593-609. http://dx.doi.org/10.1093/brain/119.2.593

Gallese, V., \& Lakoff, G. (2005). The Brain's concepts: the role of the Sensory-motor system in conceptual knowledge. Cogn Neuropsychol, 22(3), 455-479. http://dx.doi.org/10.1093/brain/119.2.593

Geschwind, N. (1970). The organization of language and the brain. Science, 170(3961), 940-944.

Glenberg, A. M., \& Gallese, V. (2012). Action-based language: A theory of language acquisition, comprehension, and production. Cortex, 48(7), 905-922. http://dx.doi.org/10.1016/j.cortex.2011.04.010

González, J., Barros-Loscertales, A., Pulvermüller, F., Meseguer, V., Sanjuán, A., Belloch, V. (2006). Reading cinnamon activates olfactory brain regions. NeuroImage, 32(2), 906-912. http://dx.doi.org/10.1016/j.neuroimage.2006.03.037

Granena, G., \& Long, M. H. (2013). Age of onset, length of residence, language aptitude, and ultimate L2 attainment in three linguistic domains. Second Language Research, 29(3), 311-343. http://dx.doi.org/10.1177/0267658312461497

Hamilton, A. F. d. C. (2013). Reflecting on the mirror neuron system in autism: A systematic review of current theories. Developmental Cognitive Neuroscience, 3(0), 91-105. http://dx.doi.org/10.1016/j.dcn.2012.09.008

Hauk, O., Johnsrude, I., \& Pulvermuller, F. (2004). Somatotopic representation of action words in human motor and premotor cortex. Neuron, 41(2), 301-307. http://dx.doi.org/10.1016/S0896-6273(03)00838-9

Hawk, T. F., \& Shah, A. J. (2007). Using Learning Style Instruments to Enhance Student Learning. Decision Sciences Journal of Innovative Education, 5(1), 1-19. http://dx.doi.org/10.1111/j.1540-4609.2007.00125.x

Hebb, D. O. (1949). The Organization of Behavior. A neuropsychological theory. John Wiley \& Sons: New York; Chapman \& Hall: London.

Herman, L. M. (2012). Body and self in dolphins. Conscious Cogn, 21(1), 526-545. http://dx.doi.org/10.1016/j.concog.2011.10.005

Iacoboni, M. (2009). Imitation, Empathy, and Mirror Neurons. Annual Review of Psychology, 60(1), 653-670. http://dx.doi.org/10.1146/annurev.psych.60.110707.163604

Iacoboni, M., \& Dapretto, M. (2006). The mirror neuron system and the consequences of its dysfunction. Nat Rev Neurosci, 7(12), 942-951. http://dx.doi.org/10.1038/nrn2024

Jones, S. S. (2009). The development of imitation in infancy. Philosophical Transactions of the Royal Society B: Biological Sciences, 364(1528), 2325-2335. http://dx.doi.org/10.1111/j.1467-9280.2007.01945.x 
King, S. L., Sayigh, L. S., Wells, R. S., Fellner, W., \& Janik, V. M. (2013). Vocal copying of individually distinctive signature whistles in bottlenose dolphins. Proceedings of the Royal Society B: Biological Sciences, 280(1757). http://dx.doi.org/10.1098/rspb.2013.0053

Kuhl, P. K. (2007). Cracking the speech code: How infants learn language. Acoustical Science and Technology, 28(2), 71-83. http://dx.doi.org/10.1250/ast.28.71

Kymissis, E., \& Poulson, C. L. (1990). The history of imitation in learning theory: the language acquisition process. J Exp Anal Behav, 54(2), 113-127. http://dx.doi.org/10.1901/jeab.1990.54-113

Lebel, C., Walker, L., Leemans, A., Phillips, L., \& Beaulieu, C. (2008). Microstructural maturation of the human brain from childhood to adulthood. NeuroImage, 40(3), 1044-1055. http://dx.doi.org/10.1016/j.neuroimage.2007.12.053

Lee, J., Fowler, R., Rodney, D., Cherney, L., \& Small, S. L. (2010). IMITATE: An intensive computer-based treatment for aphasia based on action observation and imitation. Aphasiology, 24(4), 449-465. http://dx.doi.org/10.1080/02687030802714157

Liberman, A. M., \& Mattingly, I. G. (1985). The motor theory of speech perception revised. Cognition, 21(1), 1-36. http://dx.doi.org/10.1016/0010-0277(85)90021-6

López Ornat, S., \& Gallo, P. (2004). Acquisition, learning, or development of language? Skinner's "Verbal Behavior" revisited. Spanish Journal of Psychology, 7(2), 161-170.

Macedonia, M. (1996). Lautliche Bewegungsbilder. Festschrift Universität Linz, 1(1) .

Macedonia, M. (2003). Sensorimotor enhancing of verbal memory through "Voice Movement Icons" during encoding of foreign language (German: Voice Movement Icons. Sensomotorische Encodierungsstrategie zur Steigerung der quantitativen und qualitativen Lerneffizienz bei Fremdsprachen) (PhD Thesis), University of Salzburg, Salzburg.

Macedonia, M. (2005). Games and foreign language teaching. Support for Learning, 20(3), 135-140. http://dx.doi.org/10.1111/j.0268-2141.2005.00377.x

Macedonia, M., \& Knösche, T. R. (2011). Body in Mind: How Gestures Empower Foreign Language Learning. Mind, Brain, and Education, 5(4), 196-211. http://dx.doi.org/10.1111/j.1751-228X.2011.01129.x

Macedonia, M., Müller, K., \& Friederici, A. D. (2011). The impact of iconic gestures on foreign language word learning and its neural substrate. Human Brain Mapping, 32(6), 982-998. http://dx.doi.org/10.1002/hbm.21084

Macedonia, M., \& Von Kriegstein, K. (2012). Gestures Enhance Foreign Language Learning. Biolinguistics, 6(3-4), 393-416. http://dx.doi.org/10.1016/S1053-8119(09)71138-3

Mason, L. (2009). Bridging neuroscience and education: A two-way path is possible. Cortex, 45(4), 548-549. http://dx.doi.org/10.1016/j.cortex.2008.06.003

Massen, C., \& Prinz, W. (2009). Movements, actions and tool-use actions: an ideomotor approach to imitation. Philos Trans $R$ Soc Lond B Biol Sci, 364(1528), 2349-2358. http://dx.doi.org/10.1098/rstb.2009.0059

Masur, E. F., \& Rodemaker, J. E. (1999). Mothers' and infants' spontaneous vocal, verbal, and action imitation during the second year. Merrill-Palmer Quarterly, 45(3), 392-412. 
Meltzoff, A. N., \& Moore, M. K. (1977). Imitation of facial and manual gestures by human neonates. Science, 198(4312), 75-78. http://dx.doi.org/10.1126/science.897687

Messum, P. (2012). Teaching pronunciation without using imitation: Why and how. Paper presented at the Third Annual Pronunciation in Second Language Learning and Teaching Conference Iowa State University.

Miller, G. A. (2003). The cognitive revolution: a historical perspective. Trends in Cognitive Sciences, 7(3), 141-144. http://dx.doi.org/10.1016/S1364-6613(03)00029-9

Montessori, M., \& Claremont, C. A. (1969). The absorbent mind (7th edition). Madras: Kalakshetra Publications.

Mori, S., Oishi, K., \& Faria, A. V. (2009). White matter atlases based on diffusion tensor

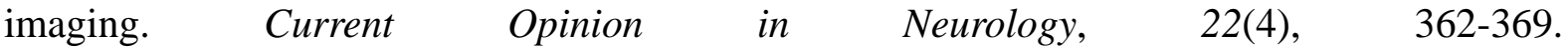
http://dx.doi.org/10.1097/WCO.0b013e32832d954b

Muñoz, C., \& Singleton, D. (2011). A critical review of age-related research on L2 ultimate attainment. Language Teaching, 44(1), 1-35. http://dx.doi.org/10.1017/S0261444810000327

Oberman, L. M., \& Ramachandran, V. S. (2007). The simulating social mind: the role of the mirror neuron system and simulation in the social and communicative deficits of autism $\begin{array}{llllr}\text { spectrum } \quad \text { disorders. } & \text { Psychol } & \text { 310-327. }\end{array}$ http://dx.doi.org/10.1037/0033-2909.133.2.310

OECD. (2002). Understanding the brain: towards a new learning science. Paris: OECD.

Olson, J., \& Masur, E. F. (2012). Mothers respond differently to infants' familiar versus non-familiar verbal imitations. Journal of Child Language, 39(4), 731-752. http://dx.doi.org/10.1017/S0305000911000262

Over, H., \& Carpenter, M. (2012). Putting the social into social learning: Explaining both selectivity and fidelity in children's copying behavior. Journal of Comparative Psychology, 126(2), 182-192. http://dx.doi.org/10.1037/a0024555

Paivio, A. (1971). Imagery and verbal processes. New York,: Holt.

Paivio, A. (2006). Dual coding theory and education. Paper presented at the Pathways to Literacy Achievement for High Poverty Children, The University of Michigan School of Education.

Pashler, H., Mc Daniel, M., Rohrer, D., \& R., B. (2009). Learning Styles - Concepts and $\begin{array}{llll}\text { Evidence. } & \text { Psychological } & \text { Science, } & \text { 9(3), }\end{array}$ http://dx.doi.org/10.1111/j.1539-6053.2009.01038.x

Pasquinelli, E. (2012). Neuromyths: Why Do They Exist and Persist? Mind, Brain, and Education, 6(2), 89-96. http://dx.doi.org/10.1111/j.1751-228X.2012.01141.x

Pennycott, A., Wyss, D., Vallery, H., Klamroth-Marganska, V., \& Riener, R. (2012). Towards more effective robotic gait training for stroke rehabilitation: a review. J Neuroeng Rehabil, 9, 65. http://dx.doi.org/10.1186/1743-0003-9-65

Perani, D., Saccuman, M. C., Scifo, P., Awander, A., Spada, D., Baldoli, C. (2011). Neural language networks at birth. Proceedings of the National Academy of Sciences of the United States of America, 108(38), 16056-16061. http://dx.doi.org/10.1073/pnas.1102991108 
Petersen, S. E., Fox, P. T., Posner, M. I., Mintun, M., \& Raichle, M. E. (1988). Positron emission tomographic studies of the cortical anatomy of single-word processing. Nature, 331(6157), 585-589. http://dx.doi.org/10.1038/331585a0

Posner, M. I., \& Rothbart, M. K. (2005). Influencing brain networks: implications for education. Trends Cogn Sci, 9(3), 99-103. http://dx.doi.org/10.1016/j.tics.2005.01.007

Prinz, W. (1997). Perception and action planning. European Journal of Cognitive Psychology, 9(2), 129-154.

Prinz, W. (2003). Experimental approaches to action. In J. Roessler \& N. Eilan (Eds.), Agency and self-awareness: issues in philosophy and psychology (pp. 165-187): Oxford: Clarendon: 2003.

Pulvermuller, F. (1999). Words in the brain's language. Behav Brain Sci, 22(2), 253-279; discussion 280-336. http://dx.doi.org/10.1017/S0140525X9900182X

Pulvermüller, F. (2002). The neuroscience of language : on brain circuits of words and serial order. Cambridge ; New York: Cambridge University Press.

Rizzolatti, G. (2005). The mirror neuron system and its function in humans. Anat Embryol (Berl), 210(5-6), 419-421. http://dx.doi.org/10.1007/s00429-005-0039-z

Rizzolatti, G., \& Craighero, L. (2004). The mirror-neuron system. Annu Rev Neurosci, 27, 169-192. http://dx.doi.org/10.1146/annurev.neuro.27.070203.144230

Rizzolatti, G., Fadiga, L., Fogassi, L., \& Gallese, V. (1999). Resonance behaviors and mirror neurons. Arch Ital Biol, 137(2-3), 85-100.

Rizzolatti, G., Fadiga, L., Fogassi, L., \& Gallese, V. (2002). From mirror neurons to imitation: Facts and speculations. In A. N. Meltzoff \& W. Prinz (Eds.), The imitative mind: development, evolution and brain bases. Cambridge: Cambridge University Press.

Saur, D., Schelter, B., Schnell, S., Kratochvil, D., Kupper, H., Kellmeyer, P. (2010). Combining functional and anatomical connectivity reveals brain networks for auditory language comprehension. NeuroImage, 49(4), 3187-3197. http://dx.doi.org/10.1016/j.neuroimage.2009.11.009

Schwier, C., van Maanen, C., Carpenter, M., \& Tomasello, M. (2006). Rational Imitation in 12-Month-Old Infants. Infancy, 10(3), 303-311.

Seitz, A. R., Kim, R., \& Shams, L. (2006). Sound facilitates visual learning. Curr Biol, 16(14), 1422-1427. http://dx.doi.org/10.1016/j.cub.2006.05.048

Setola, P., \& Reilly, R. G. (2005). Words in the brain's language: an experimental investigation. Brain Lang, 94(3), 251-259. http://dx.doi.org/10.1016/j.bandl.2004.12.007

Shams, L., \& Seitz, A. R. (2008). Benefits of multisensory learning. Trends in Cognitive Sciences, 12(11), 411-417. http://dx.doi.org/10.1016/j.tics.2008.07.006

Shams, L., Wozny, D. R., Kim, R. S., \& Seitz, A. (2011). Influences of multisensory experience on subsequent unisensory processing. Frontiers in Psychology, 2. http://dx.doi.org/10.3389/fpsyg.2011.00264 Skinner, B. F. (1957). Verbal behavior. New York,: Appleton-Century-Crofts.

Small, D. M. (2012). Flavor is in the brain. Physiology \& Behavior, 107(4), 540-552. 
http://dx.doi.org/10.1016/j.physbeh.2012.04.011

Small, S. L., Buccino, G., \& Solodkin, A. (2012). The mirror neuron system and treatment of stroke. Dev Psychobiol, 54(3), 293-310. http://dx.doi.org/10.1002/dev.20504

Soloman, B., \& Felder, R. (Retrieved 1 August 2013). Index of Learning Styles Questionnaire http://www.engr.ncsu.edu/learningstyles/ilsweb.html: North Carolina State University.

Uylings, H. B. M. (2006). Development of the Human Cortex and the Concept of "Critical" or "Sensitive" Periods. Language Learning, 56, 59-90. http://dx.doi.org/10.1111/j.1467-9922.2006.00355.x

Von Kriegstein, K., \& Giraud, A. L. (2006). Implicit multisensory associations influence $\begin{array}{llll}\text { voice recognition. } & P L o S & \text { Biology, } & 4(10),\end{array}$ http://dx.doi.org/10.1371/journal.pbio.0040326

Wernicke, C. (1874). Der Aphasische Symptomenkomplex: Eine psychologische Studie auf anatomischer Basis. Breslau: Cohn \& Weigert.

Willingham, D. T. (2009). Three problems in the marriage of neuroscience and education. Cortex, 45(4), 544-545. http://dx.doi.org/10.1016/j.cortex.2008.05.009

Zentall, T. R. (2004). Action imitation in birds. Learn Behav, 32(1), 15-23. http://dx.doi.org/10.3758/BF03196003

Zimmer, H. D. (2001). Memory for action: a distinct form of episodic memory? Oxford: Oxford University Press.

Zimmer, H. D., \& Engelkamp, J. (2003). Signing enhances memory like performing actions. Psychon Bull Rev, 10(2), 450-454. http://dx.doi.org/10.3758/BF03196505

Zwickel, J., \& Prinz, W. (2012). Assimilation and contrast: the two sides of specific interference between action and perception. Psychol Res, 76(2), 171-182. http://dx.doi.org/10.1007/s00426-011-0338-3

Van der Geer, J., Hanraads, J. A. J., \& Lupton R. A. (2000). The art of writing a scientific article. Journal of Scientific Communications, 163, 51-59

\section{Copyright Disclaimer}

Copyright reserved by the author

This article is an open-access article distributed under the terms and conditions of the Creative Commons Attribution license (http://creativecommons.org/licenses/by/3.0/). 